\title{
Markku Alanen - päätoimittaja, harrastaja ja innovaattori
}

\author{
Petri Saarikoski
}

Tietokonelehti MikroBitin pitkäaikainen päätoimittaja Markku Alanen kuoli yllättäen toukokuun lopussa. Tietotekniikan harrastajille Alanen jäi mieleen lehden tärkeänä innovaattorina, joka jätti lähtemättömän ja vahvan vaikutuksen koko Suomen tietokonekulttuuriin.

Markku Alanen ajautui lehtialalle tietokonepelien noustessa ensimmäisen kerran vakavasti otettavaksi nuorisokulttuurin ilmiöksi 1980-luvun puolivälissä. Hän kirjoitti aluksi peliarvosteluita Keskisuomalaiseen, mutta hakeutui myöhemmin syksyllä 1986 MikroBitin toimittajaksi. Omien sanojensa mukaan häntä ohjasivat ammatillisesti pelit ja 1980-luvun kotimikrojen ympärille kehittynyt tee-se-itse -kulttuuri. Hänen mukaansa "ohjelmointi oli pelaamista" ja päinvastoin.

Alasen päätoimittajauran alettua vuonna 1994, MikroBitti oli ajautunut vakavaan julkaisukriisiin. Lehden levikki oli noussut voimakkaasti 1980-luvulla, mutta 1990-luvun alkuun tultaessa kohdeyleisön saavuttaminen ei ollut enää niin helppoa, ja levikki tippui vaarallisen alhaiselle tasolle. Kotitietokonekulttuuri eli muutenkin turbulenttia aikaa, samaan aikaan kun Suomen suosituimman kotimikromerkin, Commodoren, maahantuoja oli ajautunut konkurssiin loppuvuodesta 1990. MikroBitin sisarjulkaisu, Commodore-harrastajien erikoislehti C-lehti, lopetettiin alkuvuodesta 1992. Digitaalisesta pelaamisesta oli kehittymässä oma harrastusmuotonsa, mikä näkyi markkinatilanteen ja pelilaitteiden konekirjon kasvussa. Saman kustantajan keväällä 1992 aloittama Pelit kilpaili samasta kohdeyleisöstä, ja monet vain tietokonepelaamisesta kiinnostuneet harrastajat siirtyivät uuden julkaisun tilaajiksi.

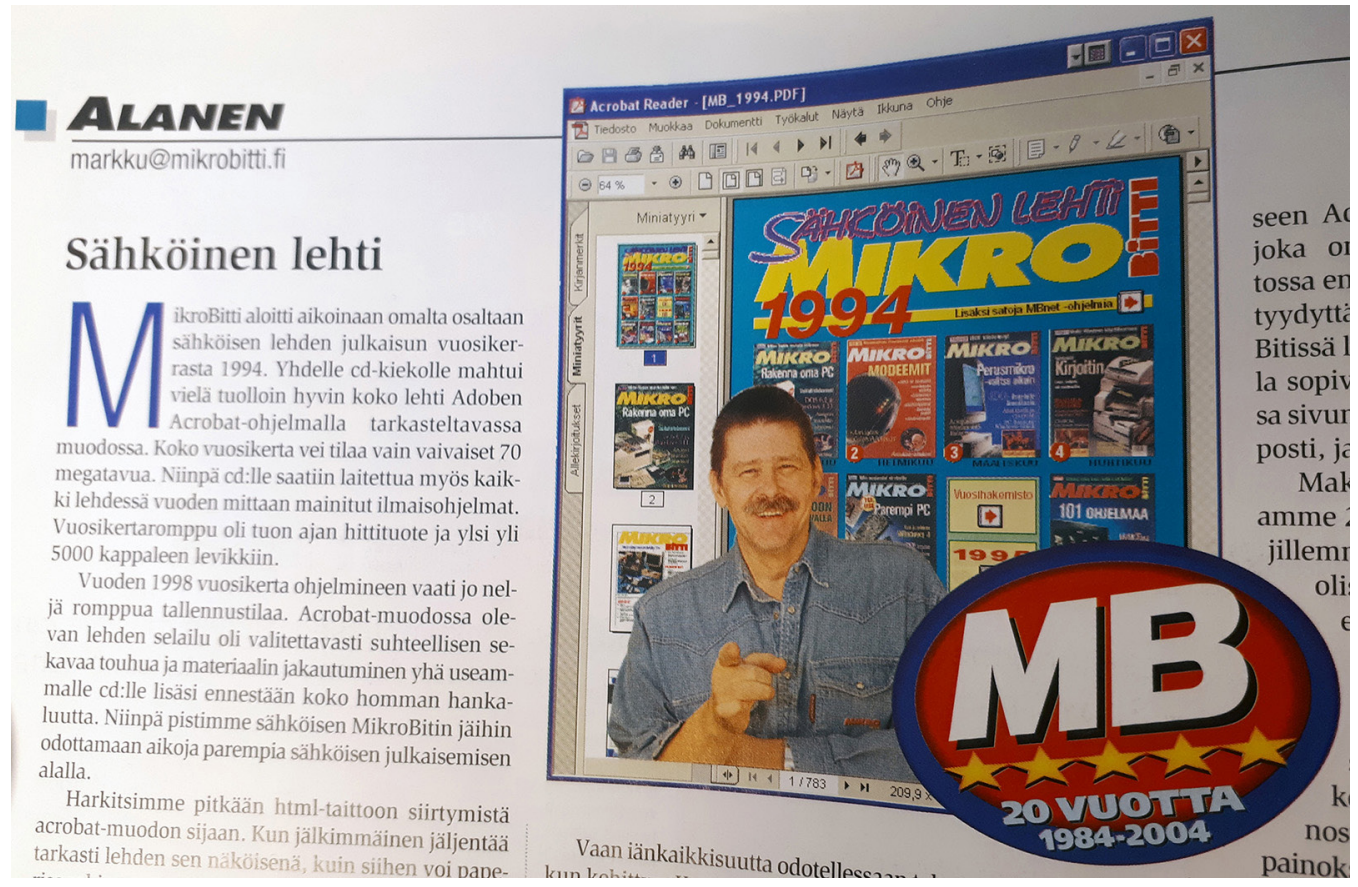

Markku Alanen. Lähde: MikroBitti 2/2004. 
PC-koneiden asema kotimikrona oli sen sijaan vakiintumassa 1990-luvun alussa. Markku Alasen johdolla MikroBitti profiloitiin PC-harrastajien erikoisjulkaisuksi, ja uusien käyttäjäryhmien etuja pyrittiin palvelemaan uskollisesti. 1980-luvulla vakiintuneiden käytäntöjen pohjalta lehden ja lukijoiden välistä yhteisöllisyyttä kehitettiin eteenpäin, ja samalla tuoreita, lahjakkaita harrastajia rekrytoitiin avustajakuntaan. Kaikkein tärkeimmäksi uudeksi innovaatioksi nousi vuonna 1994 lanseerattu sähköinen lisäpalvelu MBnet, joka toimi aluksi BBSpurkkina ja myöhemmin lehden internet-palveluna. MBnet ei ollut Suomen ensimmäinen eikä ainoa lehden sähköinen lisäpalvelu, mutta käyttäjämääriltään se kasvoi 1990-luvulla täysin omaan luokkaansa. Huippuvuosinaan 2000-luvun taitteessa MBnet oli yksi Suomen suosituimmista verkkosivustoista. Sähköisen lehtikustantamisen osalta MikroBitti olikin kiistatta aikansa johtavia edelläkävijöitä.

Markku Alasen kipparoima MikroBitti oli ennen kaikkea harrastajalehti ja tässä suhteessa Suomen tärkein PC-kulttuurin puolesta puhuja. Entiset alaiset ovat kuvanneet häntä "erityislaatuiseksi ihmiseksi”, joka johti lehteä suoraan edestä ja hukutti toimituskunnan uusiin, toteuttamista vaativiin ideoiden ja hankkeisiin. Ahkerana mikroharrastajana tunnetulle Alaselle lehden toimittaminen ei ollut selvästikään pelkkä työ vaan myös elämäntapa. Pitkälti hänen ansiostaan MikroBitin levikki oli 2000-luvun alussa yli 100.000, mikä oli täysin käsittämätön saavutus Suomen kapeilla erikoisaikakauslehtimarkkinoilla. Alanen tunnettiin myös ristiriitaisena persoonana, ja häntä ei julkaisijan johtoportaassa aina arvostettu. Värikkäiden vaiheiden jälkeen hänet siirrettiin syrjään päätoimittajan tehtävistä keväällä 2004.

Väitöskirjaprojektini yhteydessä tapasin Markku Alasen useaan otteeseen Helsingin Pitäjänmäen toimituksessa 2000 -luvun vaihteessa. Muistan hänet puheliaana ja asiasta toiseen siirtyvänä haastateltavana, jolta eivät ideat ja ajatukset loppuneet. Toisiin haastattelemiini toimittajiin erona oli myös se, että hän oli väitellyt tohtori. Hän ymmärsi siis oikein hyvin, millaisia haasteita nuorella tutkijalla oli uransa alkuvaiheessa. Sain myös mahdollisuuden kirjoittaa lehteen, ja muutamat lehtijutut julkaistiinkin melko pian haastatteluiden jälkeen.

Alasen päätoimittajauran jälkeisessä hiljaiselossa minulla oli jopa vaikeuksia toimittaa omistuskirjoituksella varustettua väitöskirjaani hänelle. Viimeisin juttu, jonka luin häneltä oli tietokonekulttuuriin erikoistuneessa Skrollissa julkaistu pitkä ja iskevä kolumni ${ }^{1}$. Näin jälkikäteen katsottuna tuo kirjoitus yhdessä toukokuun lopussa MikroBitissä julkaistun muistokirjoituksen ${ }^{2}$ kanssa tuovat väistämättä mieleen surullisen ajatuksen yhden aikakauden päättymisestä. Pääkirjoituksen lohdulliset päätössanat nostavat kuitenkin tunnelmaa: "Keep on Skrollin' 8-D”. Ei mikään ole lopullista ja päättyvää.

Hyvää matkaa Markku ja kiitos mainioista juttutuokioista!

Muistokirjoitus on julkaistu myös WiderScreen-journaalissa toukokuussa 2019.

\section{Lähteet:}

\footnotetext{
${ }^{1}$ Alanen, Markku. "MikroBitti in memoriam... ja vähän Nokiakin". Skrolli 3/2019, 14-15.

${ }^{2}$ Kärkkäinen, Henrik. "Mikroilija, innovaattori ja taiteilijasielu - päätoimittaja Markku Alanen on kuollut". Mikrobitti.fi 29.5.2019. https://www.mikrobitti.fi/uutiset/mikroilija-innovaattori-ja-taiteilijasielu-paatoimittajamarkku-alanen-on-kuollut/5fbab521-7039-4e69-bboa-a9697a946e9b.
} 